\title{
JUURNAL.RU
}

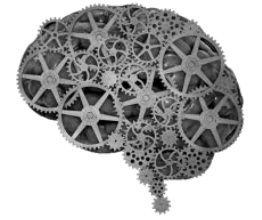

COMPANY GROUP "INTELLEKT"

\author{
Джабраилова C.P. \\ Дагестанский государственный педагогический университет \\ Махачкала, Россия
}

doi: 10.18411/lj2016-7-2-05

idsp 000001: lj2016-16-2-05

\section{Реализация концепта «окружающая среда» в английском языке}

В современном мире в окружающую среду непрерывно выбрасываются отходы, и, как следствие, происходит еѐ частичное или полное загрязнение. В конце 20 века люди стали особенно активно выступать в защиту природы, стремясь остановить еѐ варварскую эксплуатацию. Место, которое в обществе (и языке) 1980-х гг. занимал финансовый бум, перешло к экологическим проблемам - области, попавшей в сферу внимания мировой общественности в 1990-х гг. «Появился новый раздел словаря, есо-vocabulary, который незаметно вошел в ежедневную лексику людей - есо-concious, eco-speak, eco-tourism, ecorefugee. Наряду с префиксом есо- в моду вошло прилагательное green, получившее новое употребление greenery, greenism, lightgreen, darkgreen. Возникли новые проблемы и понятия, как в обществе, так и в языке biodiversity, cruelty-free, eco-labelled, ozone-friendly».B самом общем виде семантическое содержание концепта «окружающая среда» в англоязычной лингвокультуре представляется как обобщенное понятие, характеризующее природные условия в конкретно избранном месте и экологическое состояние данной местности.

Как правило, применение термина относится к описанию природных условий на поверхности Земли, состоянию еѐ локальных и глобальных экосистем, включая неживую природу, и их взаимодействие с человеком. 
Нередко в понятие «окружающая среда» включают элементы, составляющие искусственную среду (жилые строения, промышленные предприятия и инженерные сооружения и проч.). Человек, являясь неотъемлемой частью окружающей среды, не может существовать параллельно и независимо, наоборот, он существенно изменяет окружающую среду в процессе ее хозяйственного освоения. В ХХ в. в связи с загрязнением окружающей среды и усилившимся воздействием человека на природу концепт «environment» приобрел особое значение.

Воздействие человека на окружающую среду становится всѐ более ощутимым, причѐм особенно резко оно усилилось в условиях современной научно-технической революции. В разной степени изменению подверглись все природные компоненты окружающей среды. Площадь лесов на Земле сократилась в два раза, увеличилась площадь обрабатываемых земель, возникли вторичные леса и саванны, заросли кустарников, пустоши, луга. Облик земной поверхности значительно изменяют инженерные сооружения, направленные на преобразование речных систем, каналы, водохранилища и т.п. При строительных работах и добыче полезных ископаемых ежегодно перемещаются огромные массы горных пород. Однако вмешательство человека в регулирование природных процессов не всегда приносит желаемые положительные результаты, в силу того, что трудно правильно оценить отдалѐнные последствия такого воздействия. Нарушение хотя бы одного из природных компонентов приводит к перестройке сложившейся структуры природно-территориальных комплексов. Так, вырубка леса, распашка почвы, чрезмерная перегрузка пастбищ служат причинами нарушения почвенного покрова, изменения водного баланса, развития эрозии, образования пыльных бурь, перевевания песков, заболачивания и т.п.

Эти экологические изменения отражаются и в языке. Появляются понятия, номинирующие процессы, которые происходят в окружающей среде в результате хозяйственной деятельности человека (agroforestry - 'повышение 
плодородности почвы за счет посадки деревьев', overfishing - 'сокращение числа рыбы в морях', bioregionalism - ‘философия жизни в гармонии с окружающей средой', desertification - 'опустынивание'). Особенно серьѐзную угрозу для окружающей среды представляет такая деятельность, которая осуществляется без учѐта возможных вредных для окружающей среды последствий, интенсивное развитие ряда ведущих отраслей энергетики и обрабатывающей промышленности (переработка нефти, ядерная энергетика, химическая промышленность, цветная металлургия и др.), химизация сельского хозяйства, рост автомобильного, водного и авиационного транспорта. Как следствие, в языке появляются понятия waste-to-energyfacilities - 'работающие на отходах'; materials-recoveryfacilities - 'утилизация отходов'; fallout - 'радиоактивные осадки'; treefarm - 'ряд городских, промышленных труб'; strontium 90 'стронций 90’; bioweapon - ‘биологическое оружие'.

Активизация внимания к утилизации отходов жизнедеятельности человека обусловила появление новых наименований для профессии мусорщик (cantosser, garbageman, garbagecollector, garbagecompactor, garbitrageur); появляется целая наука, изучающая отходы жизнедеятельности человека как способ для понимания современного общества (garbology), и, как следствие, человека, занимающегося этой наукой, стали называть garbologist. Человек не всегда оказывает только отрицательное влияние на окружающую среду. На рубеже XX-XXI веков становятся популярными общественно-политические движения, выступающие в защиту окружающей среды. Появляются наименования этих движений, которые тоже составляют содержание концепта «environment».

Так, в семантической структуре слова «green» появился еще один лексикосемантический вариант (при этом ранее существовавшее значение сохранилось): 1) связанный с защитой окружающей среды; 2) представитель партии защитников окружающей среды; так же как и в семантике слова «garbage», которое теперь еще означает что-либо, воспринимаемое как бесполезное, нестоящее. Эти изменения в семантике слов послужили причиной появления 
целого класса двухкомпонентных неологизмов, в основе которых лежит перенос значения со свойства на субъект.

Например, метонимический перенос признака на предмет: a green ‘человек, связанный с защитой окружающей среды'. Кроме этого, отмечены случаи образования новых устойчивых сочетаний по аналогии: thegreenrevolution - ‘«зеленая» революция, увеличение урожайности с/x культур'; greenconsumers - 'люди, покупающие только те продукты, которые произведены без ущерба для окружающей среды'; greenparty - 'партия «зеленых»'; greenpolitics - 'политика охраны окружающей среды'. В этих сочетаниях значение первого элемента уточняет значение целого словосочетания (компонент green предписывает свойство 'иметь отношение к защите окружающей среды' всему словосочетанию).

Также представляет интерес группа морфологических неологизмов с префиксом есо-, являющимся смыслообразующим центром, (eco-freak 'сторонник сохранения окружающей среды'; ecofriendly - 'невредный для окружающей среды’; ecoterrorism - 'экологический терроризм'; ecotourism ‘экологический туризм'; ecowarriors - 'активисты, срывающие коммерческие мероприятия, которые могут угрожать окружающей среде'). В различных странах вопрос рационального использования ресурсов и охраны природы решается по-разному; в Англии ему уделяется большое внимание, что и отражается в лексике английского языка. В силу того, что активный интерес к окружающей среде возник у человека лишь в начале XX века, когда проблема ее загрязнения и сохранения стала острой, концепт «environment» состоит в основном из понятий, относительно недавно появившихся в языке. Поэтому представляется целесообразным попытаться определить вероятность выживаемости экологических концептов.

Очевидно, что в языке закрепляются такие новообразования, которые представляют собой наиболее закономерные для системы данного языка наименования и восполняют недостающие в нем номинативные средства. 
Анализ исследуемого материала позволил выделить 6 тематических групп, по которым лексические единицы распределены неравномерно.

Еще одна группа новообразований, которая прочно войдет в лексику языка благодаря их краткости, емкости, точности и легкости воспроизведения - это аббревиатуры и акронимы (аббревиатуры EPA (environmental protection agency); акронимы OSMA (Occupational Safety and Health Administration), HAZMAT (hazardousmaterials).

В заключение следует отметить, что экологические неологизмы имеют шансы закрепиться в языке благодаря жизнеспособности самих объектов действительности, которые они номинируют. 


\section{Литература:}

1. Краткий словарь когнитивных терминов // Е.С. Кубрякова, В.З. Демьянков, Ю.Г. Панкрац, Л.Г. Лу-зина. М.: Изд-во МГУ, 1996. 245 с.

2. Кубрякова Е.С. Об установках когнитивной науки и актуальных проблемах когнитивной лингви-стики // Вопросы когнитивной лингвистики. 2004. № 1. С. 11.

3. Воркачев С.Г. Счастье как лингвокультурный концепт. М.: ИТДГК «Гнозис», 2004. 236 с.

4. Попова 3.Д., Стернин И.А. Очерки по когни-тивной лингвистике. Изд. 3. Воронеж, 2003. 191 с.

5. Ряховская Е.М. Английский язык и английскаясоциокультура во второй половине 20 века // Вестник МГУ. Сер. 19, Лингвистика и межкультурная комму-никация. 2001. № 1. С. 50.

6. Кузнецова Н.В., Лебедева А.Н. Неологизмы в сфере экологии и их лингвистические перспективы // Иностранный язык и образовательное пространство в XXI веке. IV Региональная заочная научно- практическая конференция 20 октября 2009 года. Сборник статей. Н. Новгород: ННГУ, 2009. C. 46-49.

7. Языковая номинация: Виды наименований. М.: Издательство «Наука», 1977. $359 \mathrm{c}$. 